\title{
The Kinston-Lenoir County Public Library: A Brief History
}

The Kinston-Lenoir County Public Library, headquarters 1 of the Neuse Regional Library System, has been a vital part of the Kinston, North Carolina community for over 110 years. Within this time span, the library has moved several times as a way to accommodate the rise in population and its growing collection. Its history is evidence that the Kinston-Lenoir County Public Library's community values the services, materials, and mission of the library.

\section{Kinston's Beginnings}

In 1584, Captain Arthur Barlowe and Captain Philip Amadas encountered and communicated with Native Americans when they explored the inlands off the coast of eastern North Carolina. They soon learned of a land called Neusiok, located conveniently upon the banks of the Neuse River. ${ }^{1}$ It was here that the city of Kinston would emerge.

Kinston was established in December of "1762 as Kingston (in honor of King George III).”2 Two years later, Richard Caswell and Abraham Sheppard approached the General Assembly to recommend that Kingston be named the county seat because of its convenient location. ${ }^{3}$ This plea was unsuccessful. It was not until 1779 that a proposal to divide Kingston's current county, Dobbs, made way for it to become the county seat. In 1784, the General Assembly decided to change the name of Kingston to Kinston "because the people no longer wanted their town named for a king." ${ }^{4}$ By 1791, the
General Assembly passed a bill to abolish Dobbs County and replace it with two new counties: Lenoir and Greene. One of the new counties, Lenoir, was named in honor of Colonel William Lenoir, "a distinguished Revolutionary soldier of Wilkes County." ${ }^{5}$ In 1826, Kinston was finally incorporated. ${ }^{6}$

Kinston began to witness an increase in residents. From 1850 to 1860 , Kinston's population increased from 455 to 1,333. From 1860 to 1890 , Kinston's population grew to 1,762. By the turn of the century, 4,106 citizens called Kinston home.

\section{Along with the name}

change, a decision to open the library up to the public was made and membership tickets were issued at a fee of $\$ 1.00$ per year.

\section{The Library's Early Days}

As the population continued to increase, so did the desire to begin a literary club. In January of 1896 , Mrs. W.C. Fields began exploring the requirements of establishing a literary club, and as word began to circulate, Fields, along with Mrs. H.E.A. Peebles, Mrs. W.M. Payne, and Mrs. H.O. Hyatt, formed the Up-To-Date Club on February 4, 1896 "with the intention to stimulate a careful consideration of up-to-date topics." 8 Mrs. S.M. Harding was named the club's first president and the group quickly grew to 80 male and female members. ${ }^{9}$ Pressed to find a space to house the club's books, local dentist T.H. Faulkner graciously donated a room at his dental practice, making him the library's first librarian. ${ }^{10}$

By July of 1897, the Up-To-Date Club's membership began to dissipate. With not enough members to keep the club running as they intended, a meeting was called to decide the fate of the club's books. However, the only members to show up at the meeting were the club's officers, and it was here that the Up-To-Date Club officially changed their name to the Kinston Library. ${ }^{11}$ Along with the name change, a decision to open the library up to the public was made and membership tickets were issued at a fee of $\$ 1.00$ per year. This transition proved successful and on February 29, 1899, 40 individuals made up of former members of the Up-To-Date Club and present library subscribers "were invited to become incorporators of the Kinston Library", making it one of 57 public libraries in North Carolina at the time. ${ }^{12}$

\section{Saving Grace}

To accommodate Kinston-Lenoir County Public Library's growing collection, new space was rented above the Bank of Kinston located in the Hunter building on Queen Street. ${ }^{13}$ At this point, "the library had grown to more than a thousand volumes with an estimated value of $\$ 2,000$." ${ }^{14}$ This required the library to hire its first paid librarian, Dora Miller, to maintain the collection. Despite the move to a larger, more 
accommodating space and the goal of serving more subscribers, the library began to experience financial woes as the subscription dues were insufficient to pay for the $\$ 10.00$ per month salary of the librarian, $\$ 100$ per year for rent, as well as supplies that included "paper and pencils, 53 cents; ink, 10 cents; glue, 25 cents, 94 cents for "freight and drayage of books"; eight cents for "floor oil", and $\$ 2.50$ for five new books." 15

To assist the library in keeping their doors open, the City Board of Alderman, from the advice of Judge G.V. Cowper, decided to "subsidize the library with the sum of $\$ 12.50$ per month." 16 With the library back on track, their subscribers and collection continued to grow, and by September 1916, the library moved once again to a larger space across the street in a building owned by R.C. Blow, which was later purchased by W.T. Hines. This move, however, would not prevent the library from the possibility of closing its doors from lack of interest yet again. In 1926, a meeting was held to discuss dissolving the library and the possibility of turning its books over to the local school system. To the surprise of many, the people of Kinston came to the library's aid and with promised continual support, the library was not only saved, but the space it was currently residing in was offered rent free by W.T. Hines. ${ }^{17}$

\section{A Free County Library}

By 1932, the library had reached 98 subscribers, but with the Great Depression affecting the economic situation for the majority of the United States for the worse, the library was once again in financial trouble. After numerous failed attempts at asking the County Board of Commissioners to assume some of its financial responsibilities, the County finally “agreed to pay $\$ 20$ per month and the library was made a free county library on July 1, 1933." 18 The library's new status and financial situation rejuvenated the public's interest, and soon the library's 7,000 volumes located in the Hines building forced a relocation to the Peeble's house, an eighteenth century house owned by the Kinston Women's Club that later changed its name to Harmony Hall in the mid-1960s. ${ }^{19}$

With the library flourishing in its new location, a bookmobile was added to its list of services thanks to a North Carolina Library Association grant in 1937. With segregation an ongoing issue in the South, the Kinston-Lenoir County Public Library established a three-room space on North Independent Street for African Americans on July 3, $1938 .^{20}$

From 1940 to 1950, Kinston experienced a population increase of 2,948 people, raising their total population to 18,336 , an exceptional feat for an eastern North Carolina town at the time. ${ }^{21}$ The number of volumes the library maintained had increased to 19,409 in 1952 , which forced the library to begin searching for yet another location that could contain their growing collection. While they settled at 515 North Queen Street that October, this move was to be short-lived. In 1955, a bond issue "for $\$ 100,000$ for the construction of a new library was defeated, failing by 78 votes." 22 However, the resilience of library supporters paid off, as the library moved to the Old Sitterson House on Atlantic Avenue due to a joint action by the Lenoir County Board of Commissioners and the Kinston Aldermen. The library opened its new doors to the public on July $25,1957 . .^{23}$

\section{Creating Ties}

In 1959, the Kinston-Lenoir Count
Public Library and neighboring Greene County Library, which was founded in July 1934 by the Mother's Club of Snow Hill, created ties. ${ }^{24}$ In an effort to serve an even larger population, the library expanded to Jones County. The Maysville branch opened for service in a single room in the town's community center, a small space next to a barbershop became the home of the Pollocksville branch, and the Trenton branch took occupancy in a rented space in a local warehouse. $^{25}$ It was here, in 1962 , that the Neuse Regional Library System was formed and the KinstonLenoir County Public Library was named its Headquarters. Forming a regional library system was extremely beneficial to the patrons in the library's three-county service area, as this enabled over 150,000 volumes to circulate between them by $1976 .{ }^{26}$ Bookmobiles were also a service the library was proud to offer, as they often listed in The Kinston Free Press when and where it would be making its rounds. ${ }^{27}$

Jones County added a branch in the town of Comfort in 1976. By 1980 , Kinston reached a population of over 25,000, causing the library to consider relocating once again. The proposed destination at 310 North Queen Street was met with resistance. Commissioner Isabelle Fletcher, among others, questioned the wisdom in choosing this site and expressed concerns about its inadequate space. Library Director John Jones addressed these concerns and explained that the library "will have enough space for a 30 percent expansion of the facility if necessary." 28 With enough assurance, the Kinston City Council and the Lenoir County Commissioners agreed to help fund the library's new 20,000 square foot, $\$ 1,120,000$ project, and it opened to the public in $1983 .{ }^{29}$ 
As the Kinston-Lenoir County Public Library began serving the community in their new and much larger facility, negotiations were taking place to add additional Lenoir County branches to the Neuse Regional Library System. In July 1984, the town of Pink Hill established a branch library when a quaint building and lot were donated in memory of resident Etta Jones Turner. $^{30}$ In addition, the town of LaGrange opened a branch library on May 2, 1991 in a remodeled 15,000 square foot building located on East Washington Street. ${ }^{31}$

\section{Expanding Minds, Building Dreams}

With eight entities now making up the Neuse Regional Library System, citizens from Lenoir, Greene, and Jones counties were ensured access to information. However, this did not stop the Kinston-Lenoir County Public Library from expanding to ensure their Queen Street space would hold their growing collection and materials and ensure adequate space for patrons. A renovation project, which was approved in 2004, led the way to a $\$ 3,600,000$ renovation project, of which $\$ 2,600,000$ came from a bond referendum, and the additional $\$ 1,000,000$ coming from federal grants and private donations. ${ }^{32}$ The library kept its doors open during the entire two-year renovation, which saw construction workers inside the library busy at work. ${ }^{33}$ The renovation expanded the library by 9,000 square feet, making the finished product almost 30,000 square feet.

\section{Serving in the 21st Century and Beyond}

To ensure that the Kinston-Lenoir County Public Library is meeting the needs of the patrons in their

\section{...in an effort to offer their patrons the latest in technology, the Kinston-Lenoir County Public Library became one of the first public libraries in eastern North Carolina to begin circulation of E-Readers.}

community, many projects have been undertaken by over fifty full-time and part-time staff. The library offers 39 computers for adult use and 16 computers for child use, which allows them to search the Internet and the multiple databases that are offered. Also available is the new TLC LS2 Online Public Access Catalog (OPAC) that allows patrons to search the entire Neuse Regional Library System for materials. The library also received a \$100,000 Golden Leaf grant in 2010 to combat adult illiteracy in Lenoir County by acquiring a variety of literacy materials and matching students with qualified instructors. $^{34}$ Furthermore, in an effort to offer their patrons the latest in technology, the Kinston-Lenoir County Public Library became one of the first public libraries in eastern North Carolina to begin circulation of E-Readers.

Programming is another service the library is well known for in their community, as the programs they offer reflect the diversity of the patrons they serve. Programs include children's story times held multiple times per week at various branches, video game tournaments for young adults, book talking groups for adults, and musical programs and educational lectures that are attended by patrons of all ages. Due to the countless variety of programs offered, the library serves as an organization of life long learning in its community.

The Kinston-Lenoir County Public Library is a testament to the citizens of Kinston. When faced with losing their information outlet, they banded together and made their voices heard, ensuring that not only themselves, but also future generations would have a public library to call their own.

\section{References}

1 William S. Powell, Annals of Progress: The Story of Lenoir County and Kinston, North Carolina (Raleigh: State Department of Archives and History, 1963), 6.

2 William S. Powell, ed., Encyclopedia of North Carolina (Chapel Hill: The University of North Carolina Press, 2006), 669.

3 Talmage C. Johnson and Charles R. Holloman, The Story of Kinston and Lenoir County (Raleigh: Edwards \& Broughton Company, 1954), $27-$ 28.

${ }^{4}$ Ibid., 30.

5 Ibid., 78.

6 Powell, Annals of Progress: The Story of Lenoir County and Kinston, North Carolina, 38.

7 Ibid., 5.

${ }^{8}$ Mike Kohler, 200 Years of Progress: A Report of the History and Achievements of the People of Lenoir County (Kinston, NC: KinstonLenoir County Bicentennial Commission, 1976), 142.

9 William S. Powell, Annals of Progress: The Story of Lenoir County and Kinston, North Carolina, 67.

${ }^{10}$ Kohler, 200 Years of Progress: A Report of the History and Achievements of the People of Lenoir County, 142.

${ }^{11}$ Ibid.

${ }^{12}$ Powell, Annals of Progress: The Story of Lenoir County and Kinston, North Carolina, 67. 
${ }^{13}$ Ibid.

${ }^{14}$ Kohler, 200 Years of Progress: A Report of the History and Achievements of the People of Lenoir County, 142.

${ }^{15}$ Ibid.

${ }^{16}$ Ibid., 143.

${ }^{17}$ Ibid.

${ }^{18}$ Ibid.

${ }^{19}$ Powell, ed., Encyclopedia of North Carolina, 551.

${ }^{20}$ Kohler, 200 Years of Progress: A Report of the History and Achievements of the People of Lenoir County, 143.

${ }^{21}$ Powell, Annals of Progress: The Story of Lenoir County and Kinston, North Carolina, 5.

${ }^{22}$ Kohler, 200 Years of Progress: A Report of the History and Achievements of the People of Lenoir County, 143.

${ }^{23}$ Ibid.

${ }^{24}$ James M. Creech, History of Greene County, North Carolina (Baltimore, Gateway Press, Inc., 1979), 469.

25 "Jones County Libraries Mark Anniversary," The Kinston Free Press, 11 June 2006.

${ }^{26}$ Kohler, 200 Years of Progress: A Report of the History and Achievements of the People of Lenoir County, 143.

27 "Bookmobile," The Kinston Free Press, 26 January 1962.

${ }^{28}$ Ken Hamrick and John McCurry, "Library May Be Finished In Early 1983, Jones Says," The Kinston Free Press, n.d.

${ }^{29}$ Ibid.

${ }^{30}$ Christine W. Williams, "Pink Hill Library Circulation Soars," Pink Hill Review, 16 May 1991.
${ }^{31}$ Mary Elizabeth Gray, LaGrange, Its Origin and History (North Carolina: M.E. Gray, 1997), 217.

${ }^{32}$ David Anderson, "Expansion Unveiled," The Kinston Free Press, 17 April 2008.

${ }^{33}$ David Anderson, "Library Renovations Complete," The Kinston Free Press, 29 May 2008.

${ }^{34}$ David Anderson, "Golden Leaf Approves \$1.3 Million in Grants," The Kinston Free Press, 11 February 2010.

\section{Selected Bibliography}

Anderson, David. "Expansion Unveiled." The Kinston Free Press, 17 April 2008, accessed 25 August, 2010, http://www.kinston.com/ news/library-45854-children-county. html.

Anderson, David. "Golden Leaf Approves \$1.3 Million in Grants." The Kinston Free Press, 11 February 2010, accessed 9 November 2010, http://www.kinston.com/news/ grant-61987-city-board.html.

Anderson, David. "Library Renovations Complete." The Kinston Free Press, 29 May 2008, accessed 19 March 2011, http://www.kinston. com/news/library-46776-reallyrenovations.html.

"Bookmobile." The Kinston Free Press. 26 January 1962.

Creech, James M. History of Greene County, North Carolina. Baltimore,
Gateway Press, Inc., 1979.

Gray, Mary Elizabeth. LaGrange, Its Origin and History, North Carolina: M.E. Gray, 1997.

Hamrick, Ken \& McCurry, John. "Library May Be Finished In Early 1983, Jones Says.” The Kinston Free Press, n.d.

Johnson, Talmage C. \& Holloman, Charles R. The Story of Kinston and Lenoir County. Raleigh: Edwards \& Broughton Company, 1954.

"Jones County Libraries Mark Anniversary." The Kinston Free Press, 11 June 2006, accessed 25 August, 2010, http://www.kinston. com/articles/branch-5754-librarylibraries.html.

Kohler, Mike. 200 Years of Progress: A Report of the History and Achievements of the People of Lenoir County. Kinston, NC: Kinston-Lenoir County Bicentennial Commission, 1976.

Powell, William S. Annals of Progress: The Story of Lenoir County and Kinston, North Carolina. Raleigh: State Department of Archives and History, 1963.

Powell, William S. ed. Encyclopedia of North Carolina. Chapel Hill: The University of North Carolina Press, 2006.

Williams, Christine W. "Pink Hill Library Circulation Soars." Pink Hill Review, 16 May 1991.

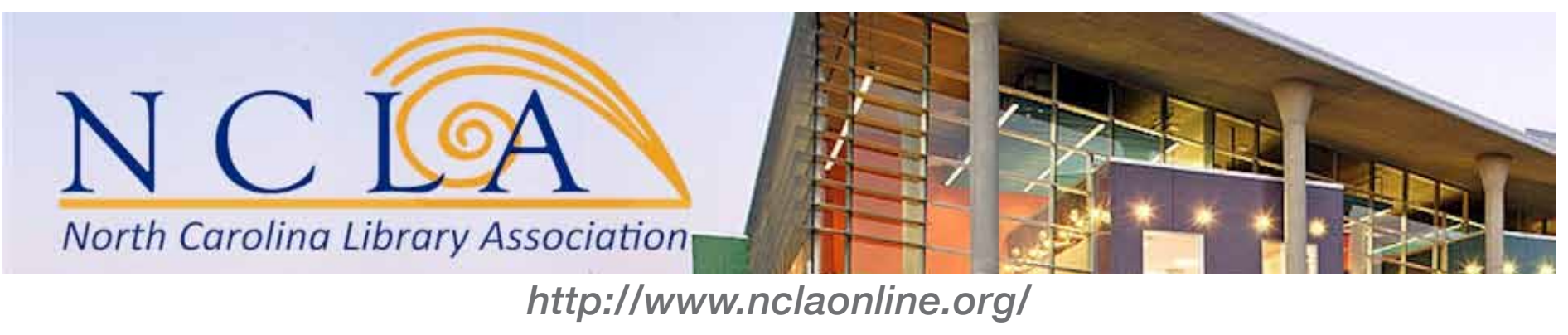

